\title{
Water isotopes in desiccating lichens
}

\author{
Britta Hartard · Matthias Cuntz · Cristina Máguas • \\ Michael Lakatos
}

Received: 14 July 2009/Accepted: 8 October 2009/Published online: 4 November 2009

(C) Springer-Verlag 2009

\begin{abstract}
The stable isotopic composition of water is routinely used as a tracer to study water exchange processes in vascular plants and ecosystems. To date, no study has focussed on isotope processes in non-vascular, poikilohydric organisms such as lichens and bryophytes. To understand basic isotope exchange processes of non-vascular plants, thallus water isotopic composition was studied in various green-algal lichens exposed to desiccation. The study indicates that lichens equilibrate with the isotopic composition of surrounding water vapour. A model was developed as a proof of concept that accounts for the specific water relations of these poikilohydric organisms. The approach incorporates first their variable thallus water potential and second a compartmentation of the thallus water into two isotopically distinct but connected water pools. Moreover, the results represent first steps towards
\end{abstract}

B. Hartard $(\square) \cdot$ M. Lakatos

Department of Experimental Ecology,

University of Kaiserslautern, P.O. Box 3049, Erwin-

Schroedinger-Str. 14/262, 67653 Kaiserslautern, Germany

e-mail: Britta.Hartard@Forst.bwl.de

M. Lakatos

e-mail: lakatos@rhrk.uni-kl.de

B. Hartard · C. Máguas · M. Lakatos

Stable Isotopes Laboratory, Centre for Environmental Biology,

FCUL, University of Lisbon, Campo Grande

1749-016 Lisbon, Portugal

M. Cuntz

Max-Planck Institute for Biogeochemistry,

P.O. Box 100164, 07701 Jena, Germany

Present Address:

M. Cuntz

UFZ, Helmholtz Centre for Environmental Research,

Permoserstr. 15, 04318 Leipzig, Germany the development of poikilohydric organisms as a recorder of ambient vapour isotopic composition.

Keywords Cryptogams $\cdot \delta^{18} \mathrm{O}$ discrimination . Isotope equilibration - Modelling · Vapour .

Water exchange
Abbreviations
CA Carbonic anhydrase
CAM Crassulacean acid metabolism
DW Dry weight
RH Relative humidity
RWC Relative water content

\section{List of symbols}

E Transpiration

$g_{\mathrm{t}} \quad$ Total conductance for water vapour of stomata

and boundary layer

$h_{\mathrm{s}} \quad$ Air relative humidity corrected to lichen temperature

$k_{\text {ex }} \quad$ Hypothetical exchange coefficient

$R_{\mathrm{a}} \quad$ Isotopic composition of atmospheric water vapour

$R_{\mathrm{E}} \quad$ Isotopic composition of evaporated water

$R_{\text {eq }} \quad$ Isotopic equilibrium of water with water vapour

$R_{\mathrm{L}} \quad$ Isotopic composition of leaf water

$R_{\mathrm{M}} \quad$ Isotopic composition of maximum enrichment

$T_{\mathrm{L}} \quad$ Leaf/Lichen temperature

$V_{\text {dry }} \quad$ Weight of the dry lichen

$V_{\mathrm{L}} \quad$ Leaf/Lichen water volume

$V_{\text {wet }} \quad$ Weight of the lichen at maximum water content

$w_{\mathrm{a}} \quad$ Atmospheric water mole fraction

$\mathrm{WC}_{\max }$ Maximum water content

$w_{\text {sat }} \quad$ Saturation water mole fraction

$\Psi \quad$ Water potential

$\alpha^{+} \quad$ Equilibrium fractionation factor 
$\alpha_{\mathrm{k}} \quad$ Kinetic fractionation factor

$\tau \quad$ Turnover time

\section{Introduction}

The isotopic composition of water is a natural tracer that is widely used in hydrological research in order to provide new insights into some of the underlying processes. Prominent examples are recharge rates of groundwater (Gibson et al. 2002) and river catchment hydrology (cf. Kendall and McDonnell 1998). Within hydrological research, isotopes give a new perspective on the water cycle (Gat 2000) and, for that matter, they also link the hydrological cycle with plant ecology. As plants transpire about $50 \%$ of the water on land, they are one of the major drivers of the water cycle (Dirmeyer et al. 2006). Because different pools of water in an ecosystem can easily be distinguished by water isotopes, this approach also helps to clarify the different strategies of plants to acquire water (e.g. Dawson 1998). Stable isotopes of water are routinely used, for example, to partition ecosystem water fluxes into evaporation and transpiration fluxes (Yakir and Wang 1996) and to determine water recycling rates on continental scales (Gat and Matsui 1991).

All applications rely on accurate assessment of the isotopic composition of the respective water pools. Techniques to sample and analyse liquid water are well established; however, it is much more difficult to adequately collect atmospheric water vapour. Commonly, air moisture is cryogenically trapped and later analysed in the laboratory (Helliker et al. 2002). Recent technological advances such as tuneable diode lasers or cavity ring-down spectroscopy now allow instantaneous measurements of water isotopes in the field (Lee et al. 2006). However, all of these methods involve laborious and costly equipment and require availability of liquid nitrogen, dry ice and electric power.

Thus, the possibility to use a natural tracer that reflects the vapour isotopic signal of its surroundings would highly facilitate the monitoring of ambient moisture isotopic compositions. Lai et al. (2008) proposed using the isotopic composition of leaf water just before sunrise as a measure of vapour isotopic composition. This is because steady-state leaf water enrichment comes to isotopic equilibrium with water vapour at very high relative humidity (Craig and Gordon 1965), which often occurs at night. The small numbers of simultaneous observations of leaf water enrichment and water vapour isotopes at night seem to support this view (Langendörfer et al. 2002; Lai et al. 2006). However, the degree of equilibration depends on the turnover rate of leaf water by water vapour, and hence on stomatal conductance at night and leaf water volume (cf. Cuntz et al. 2007). Leaf water enrichment is therefore no reliable measure of water vapour isotopic composition. It also only records the isotope value at the end of the night and not its diurnal variations, which may be several per mill depending for example on canopy structure and leaf area index (Lai et al. 2006). Recently, Helliker and Griffiths (2007) pointed out that any plant which only operates at high relative humidity could be used as a proxy for ambient vapour isotopic composition. They showed that the leaf water of the epiphytic crassulacean acid metabolism (CAM) plant Tillandsia usneoides resembles the isotopic ratio of liquid water in equilibrium with atmospheric vapour in a predictive manner since it is independent of soil water supply and opens its stomata only at night. Yet, T. usneoides took about 3-4 days to reach full isotopic equilibrium with ambient vapour. In addition, this approach can only assess the isotopic composition at night and/or in ecosystems that first reach high relative humidity and second do not show too large variations in vapour isotopic composition during consecutive nights. In this respect, lichens may provide a way to overcome the limitations of higher plants because of their specific inherent water relations (cf. Lakatos et al. 2007; Hartard et al. 2008). In contrast to homoiohydric vascular plants, non-vascular cryptogams such as cyanobacteria, algae, lichens and bryophytes follow an alternative strategy of hydration: (1) they have reasonably small absolute water contents and (2) their water status varies with surrounding conditions (e.g. Blum 1973). These poikilohydric organisms are desiccation-tolerant, surviving drought in an anabiotic state until water becomes available. This strategy has proven to be successful, particularly in ecosystems where vascular plants reach their ecophysiological limits due to adverse climatic conditions (Kappen 1988; Lange et al. 1992; Belnap et al. 2001). Lichens in particular present a worldwide distribution, even in the driest habitats. Their symbiotic relationship consists of a fungal partner, the 'mycobiont', and its photosynthetic associate, the 'photobiont'. Approximately $45 \%$ of the lichen-forming fungi develop stratified thalli (heteromerous lichens) which are structured in various layers (Honegger 1993; also see Table 1a). Despite this internal stratification, lichens furthermore exhibit different growth forms, such as crustose (crust-forming), foliose (leaf-like) and fruticose (shrub-like) types (reviewed by Honegger 2006).

Lichens' poikilohydric nature is based on a lack of vascular tissue and concurrent missing continuous water supply as well as a lack of specific features, e.g. stomata, to control water deficit. Their water status varies passively with surrounding conditions and, consequently, they are subject to frequent desiccation. During desiccation events, lichen relative water content (RWC) may drop down to $10-15 \%$ of its maximum value at water saturation (e.g. Blum 1973; Rundel 1988). Correspondingly, thallus' water potential ( $\Psi$ ) decreases and approaches that of the environment (e.g. Jonsson et al. 2008). In contrast to vascular plants, they are 
specialised to utilise a variety of different water sources such as soil water, precipitation, dew and fog. Particularly green algal lichens, which constitute about $85 \%$ of all lichens (Honegger 1997), and also some mosses are even able to reactivate photosynthesis by rehydration with water vapour only (Lange 1969; Lange et al. 2001).

The constant approach of lichens to a physical equilibrium with their immediate environment enhances their potential suitability as natural indicators/tracers of ambient vapour isotopic composition. The processes affecting oxygen stable isotopes during poikilohydric water exchange are yet unknown because until now mostly vascular, homoiohydric plants have been under investigation. Recently, a rootless epiphytic CAM plant, T. usneoides, exposed to varying environmental moisture conditions was investigated (Helliker and Griffiths 2007; Reyes-García et al. 2008). In terms of water relations, vascular epiphytes are similar to non-vascular lichens in that they also lack constant water supply. Helliker and Griffiths (2007) concluded that the leaf water isotopic composition, $R_{\mathrm{L}}$, of $T$. usneoides is controlled by atmospheric water vapour, $R_{\mathrm{a}}$. Basically the Helliker and Griffiths (2007) single-source model has the same form as the non-steady state leaf water enrichment model of Farquhar and Cernusak (2005), which means that leaf water exposed to new environmental conditions exponentially approaches a new equilibrium value (cf. Appendix 1):

$R_{\mathrm{L}}(t+\mathrm{d} t)=R_{\mathrm{M}}+\left[R_{\mathrm{L}}(t)-R_{\mathrm{M}}\right] \exp \{-\mathrm{d} t / \tau\}$.

In the case of vascular plants the equilibrium value, $R_{\mathrm{M}}$, is the Craig and Gordon steady-state prediction corrected for the Péclet effect (cf. Cuntz et al. 2007), whereas in the case of non-vascular plants it is the maximum possible enrichment, i.e. leaf water is so enriched that the evaporated water, $R_{\mathrm{E}}$, has the same isotopic composition as the liquid water at the evaporating surface $R_{\mathrm{E}}=R_{\mathrm{L}} \equiv R_{\mathrm{M}}$ :

$R_{\mathrm{M}}=\frac{h_{\mathrm{s}}}{1-\alpha_{\mathrm{k}} \alpha^{+}\left(1-h_{\mathrm{s}}\right)} R_{\mathrm{eq}} \quad$ with $R_{\mathrm{eq}}=a^{+} R_{\mathrm{a}}$.

The $\alpha$ 's $(>1)$ are kinetic $\left(\alpha_{\mathrm{k}}\right)$ and equilibrium $\left(\alpha^{+}\right)$ fractionation factors (Majoube 1971; Cappa et al. 2003) and $h_{\mathrm{s}}$ is air relative humidity corrected to leaf temperature: $h_{\mathrm{s}}=w_{\mathrm{a}} / w_{\text {sat }}\left(T_{\mathrm{L}}\right) \quad\left(w_{\mathrm{a}}\right.$ : atmospheric water mole fraction, $w_{\text {sat }}\left(T_{\mathrm{L}}\right)$ saturation water mole fraction at temperature $\left.T_{\mathrm{L}}\right)$. $R_{\mathrm{M}}$ tends towards $R_{\mathrm{eq}}$, i. e. isotopic equilibrium with water vapour when relative humidity tends towards unity. (The expressions 'isotopic equilibrium with water vapour' and 'is equilibrated isotopically with water vapour' are used in the following synonymously with $R_{\text {eq. }}$.) This maximum enrichment $R_{\mathrm{M}}$ can also be observed in monocot leaves where the leaf tips tend towards $R_{\mathrm{M}}$ (Farquhar and Gan 2003 ) or in so-called desert rivers, water streams that have no effluent (Fontes and Gonfiantini 1967). The time (constant) to reach equilibrium is the turnover time, $\tau$, i.e. leaf water volume $V_{\mathrm{L}}$ in relation to the exchange flux with the atmosphere. In vascular plants $\tau \approx V_{\mathrm{L}} / g_{\mathrm{t}} w_{\mathrm{sat}}\left(T_{\mathrm{L}}\right)$, i.e. the leaf water volume $V_{\mathrm{L}}$ is turned over by the one-way water flux from the leaf to the atmosphere, $g_{\mathrm{t}} w_{\text {sat }}\left(T_{\mathrm{L}}\right)$ [and not simply transpiration $E$ (cf. Dongmann and Nürnberg 1974; Farquhar and Cernusak 2005)], with $g_{\mathrm{t}}$ being the total conductance for water vapour of stomata and boundary layer. In contrast, in non-vascular plants this turnover is given as $\tau \approx V_{\mathrm{L}} / g_{\mathrm{t}} w_{\mathrm{a}}$. This means that the leaf water volume $V_{\mathrm{L}}$ in non-vascular plants is turned over by the one-way water flux from the atmosphere into the leaf, exactly opposite to vascular plants (cf. Appendix 1). The Helliker and Griffiths (2007) single source model was developed for CAM epiphytes that lack constant water supply. So the model should consequently also apply to lichens though lichens should reach steady state much faster because of their lower water content.

Within the present study, (1) the mechanisms driving oxygen isotope variability in the thallus water of lichens are addressed by examining its $\delta^{18} \mathrm{O}$ performance in different green-algal lichens experiencing dehydration, and (2) the applicability of the single-source model (Helliker and Griffiths 2007) to describe water exchange processes of lichens is tested and evaluated.

Additionally, the ${ }^{18} \mathrm{O}$ isotopic signal of $\mathrm{CO}_{2}$ that is released by the lichens was assessed. $\delta^{18} \mathrm{O}$ of water is passed onto $\mathrm{CO}_{2}$ via hydration of dissolved $\mathrm{CO}_{2}$. In the presence of carbonic anhydrase (CA) - an enzyme that catalyses the interconversion of $\mathrm{CO}_{2}$ and bicarbonate-this process is much accelerated (Silverman 1982). Intracellular as well as extracellular CA also frequently occurs in lichens (Palmqvist and Badger 1996). Previous studies on vascular plants with high CA activity showed that, while leaf water $\delta^{18} \mathrm{O}$ may be markedly heterogeneous (Yakir et al. 1989), any released $\mathrm{CO}_{2}$ is in isotopic equilibrium with water at the evaporative site of the leaf (Gillon and Yakir 2000; Cousins et al. 2006). Transferring this to lichens suggests that the isotopic signal of $\mathrm{CO}_{2}$ released from the thallus reflects the water located in surface structures, whereas directly measured thallus water $\delta^{18} \mathrm{O}$ may represent the more heterogeneous bulk thallus water (Lakatos et al. 2007; Hartard et al. 2008).

\section{Materials and methods}

Lichen material, collection, storage and preconditioning

Four distinct lichen species have been selected according to their differences in morphology and ecological preferences of micro-habitat. All species were collected in a Mediterranean sand dune ecosystem in Osso de Baleia, western Portugal $\left(40^{\circ} 0^{\prime} \mathrm{N}, \quad 08^{\circ} 54^{\prime} \mathrm{W}\right)$. For a more detailed 
Table 1 a Morphological scheme of fruticose (left) and foliose (right) lichens. b Illustrations and morphological characteristics of the four studied green-algal lichen species

(a)

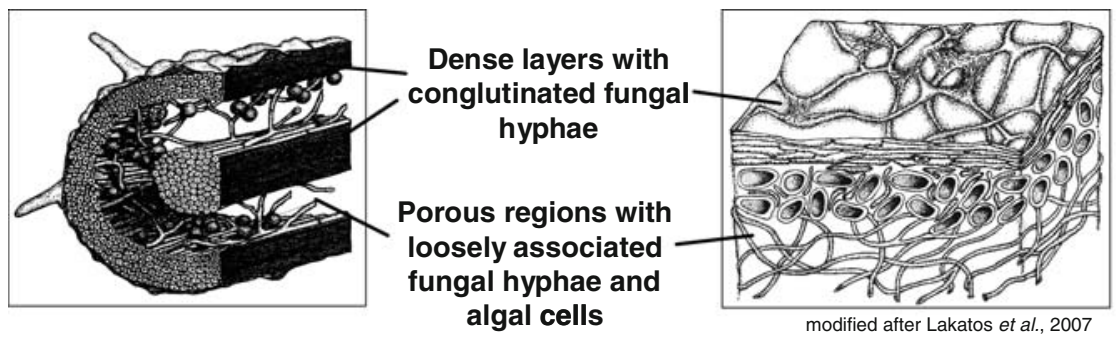

(b)

\begin{tabular}{|c|c|c|c|c|c|c|}
\hline \multicolumn{3}{|c|}{ Species } & Parmelia caperata & Cladonia convoluta & Cladina arbuscula & Usnea filipendula \\
\hline \multicolumn{3}{|c|}{ Habitat } & corticolous & terricolous & terricolous & corticolous \\
\hline \multicolumn{3}{|c|}{$\mathrm{WHC}\left[\mathrm{g}\left(\mathrm{H}_{2} \mathrm{O}\right) \mathrm{g}(\mathrm{DW})^{-1}\right]$} & $2.3 \pm 0.3$ & $1.5 \pm 0.2$ & $2.6 \pm 0.2$ & $1.2 \pm 0.1$ \\
\hline \multirow{6}{*}{$\begin{array}{l}\text { Morphological } \\
\text { characteristics }^{(1)}\end{array}$} & Growth & form & foliose & fruticose, foliose-like & fruticose & fruticose \\
\hline & \multicolumn{2}{|c|}{ Surface/Volume ratio } & low & low & high & high \\
\hline & \multirow{2}{*}{$\begin{array}{l}\text { Conglutinated } \\
\text { thallus structures }\end{array}$} & at thallus surface & upper and lower cortex & upper cortex & - & all enclosing cortex \\
\hline & & inside thallus & - & - & central cylinder & central strand \\
\hline & \multicolumn{2}{|c|}{$\begin{array}{l}\text { Surface layers } \\
\text { (cortex and algal layer) } \\
{[\% \text { of total] }}\end{array}$} & $21 \pm 4$ & $30 \pm 7$ & $49 \pm 7$ & $71 \pm 20$ \\
\hline & \multicolumn{2}{|c|}{$\begin{array}{c}\text { Internal structures } \\
\text { (medulla and central strand/cylinder) } \\
\text { [\% of total] }\end{array}$} & $79 \pm 4$ & $70 \pm 7$ & $51 \pm 7$ & $29 \pm 20$ \\
\hline
\end{tabular}

Upper pictures show the lichens' habitus in their natural associations; lower pictures show cross sections of the lichens with their respective morphological characteristics. Values are the mean $( \pm \mathrm{SD})$ of five thalli replicates with each replicate representing mean values of ten cross sections measured for each thallus

description of the collection site see Hartard et al. (2008). Whereas Usnea filipendula Stirton s.str. and Parmelia caperata (L.) Ach. are corticolous (on bark growing) species exposed to rather xeric conditions, Cladonia convoluta (Lam.) Anders and Cladina arbuscula (Wallr.) Hale and W.Culb. are typical terricolous (ground growing) lichens influenced by soil moisture. This particularly applies to the latter $C$. arbuscula that-in its natural habitat-conglomerates in large cushion-like associations (Table $1 b$ ).

After collection, samples were air-dried and kept in the refrigerator at $4^{\circ} \mathrm{C}$ for up to 4 weeks before conducting laboratory experiments.

Assessment of the lichen morphology

Several studies have shown that the progress of water exchange in lichens strongly depends on morphological properties, in particular on the existence and size of different thallus structures such as dense layers with thickwalled fungal hyphae versus areas with more loosely associated cells and hydrophobic cell walls (cf. Blum 1973; Bewley 1979; Rundel 1988). Depending on the investigated species, these layers can be found either on the thallus surface (e.g. outer cortices and algal layer) or inside the thallus (e.g. medulla and central strands) (Table 1a). Consequently, water located in these distinct regions is more or less exposed to the surrounding atmosphere and to associated isotopic exchange processes. To investigate the effect of such morphologically distinct layers and their relative exposition to ambient air on the oxygen stable isotope composition of the thallus water, each species' specific internal stratification was assessed. The thickness of each observed layer was measured and the relative volume of each layer was subsequently calculated in order to obtain an approximation of the size of the water pools present in each of the distinct thallus layers. 
For this, cross sections of each species were made using a freezing microtome (Reichert-Jung, Heidelberg, Germany). The cross sections were investigated microscopically and thickness of the thallus as well as of each structurally distinct thallus layer was measured quantitatively using an ocular micrometer. Five thalli of each species were randomly selected and ten cross sections of $40 \mu \mathrm{m}$ thickness were prepared from each thallus. Each cross section represents the mean of five pseudo-replications (measured at five different positions) and the mean of ten cross sections was used to represent one replicate, i.e. thallus.

\section{Dehydration experiment}

To identify the mechanisms driving ${ }^{18} \mathrm{O}$ variability in lichens, a laboratory experiment was conducted and the oxygen isotope processes of the thallus water of the studied lichen species during dehydration were monitored. For this, the acclimated lichen samples were submersed in tap water for $30 \mathrm{~min}$ prior to the experiment to ensure initial watersaturation. Subsequently, the samples were slightly blotted to remove any excess water, and fresh weight at maximum water content $\left(\mathrm{WC}_{\max }\right)$ was determined using an analytical balance (MC1 Analytic, Sartorius, Epsom, UK; accuracy: $0.1 \mathrm{mg}$ ). Except for three samples, which served as control, all other samples were placed into a darkened Plexiglas container and closed with a perforated lid, to allow homogeneous dehydration similar to natural conditions. Due to the highly fragile nature of lichens and to create a natural boundary layer, the air inside the container was not stirred by a vent. The control samples were immediately transferred into small, tight plastic containers to avoid any further dehydration until the start of the isotopic analysis. To ensure constant environmental conditions, the dehydration experiment was conducted within a climate chamber which supplied constant temperature of an average $25^{\circ} \mathrm{C}$ and $60 \%$ relative humidity ( $\left.\mathrm{RH}\right)$. Humidity conditions inside the Plexiglas container were measured in pre-experiments using the same experimental set-up and processing and measuring relative humidity with a small microclimatic data logger (HoboPro, Onset, MA, USA) programmed to record $\mathrm{RH}$ data once every minute throughout the whole pre-experiment. The measurements showed that immediately after placing the water-saturated samples inside the container, RH increased up to approximately $85 \%$. This high RH remained approximately constant for $2.5-3 \mathrm{~h}$ and subsequently steadily decreased, approaching humidity conditions of the surrounding air of the climate chamber $(60 \%)$. However, throughout the experiment, short periods down to $60 \% \mathrm{RH}$ also occurred after each sampling collection due to the opening of the lid. During the dehydration experiment, which lasted for $7 \mathrm{~h}$, every hour a set of at least three samples of each species was removed from the container. Each sample was placed into an individual pre-weighed exetainer (Labco Limited, Buckinghamshire, UK) and sealed with a gastight Teflon septum cap. Exetainers were wrapped in aluminium foil to ensure dark respiration and flushed with $\mathrm{CO}_{2}$-free air. This was done by penetrating the exetainers' Teflon septum with two needles and flushing them with atmospheric air directed through a soda lime column. The outgoing air was directed into an absolute $\mathrm{CO}_{2}$ infrared gas analyser (Binos100, Leybold-Heraeus GmbH, Hanau, Germany). Once the air coming out proved to be $\mathrm{CO}_{2}$-free, the needles were removed and the lichens were left to respire for at least $10 \mathrm{~min}$. A pre-experiment was conducted to investigate the lichens' respiration rates. Since they were found to be highly species specific and mainly dependent on the prevailing water status, specific respiration times were adjusted according to the expected respiration rates of the individual samples. In this way, the amount of respired $\mathrm{CO}_{2}$ inside the exetainers was similar for all samples $(359 \pm 196 \mathrm{ppm})$ at the time of isotopic analysis. The effect of the flushing with $\mathrm{CO}_{2}$-free air on the isotopic composition of the thallus water was also tested. Prior to the experiment, individual samples were repeatedly flushed and each time subsequent isotopic analysis of the lichen's respired $\mathrm{CO}_{2}$ were performed. These experiments did not show significant effects of the flushing on the $\mathrm{CO}_{2}$ isotopic composition of the samples (data not shown).

\section{Isotopic analysis of respired $\mathrm{CO}_{2}$}

For isotopic analysis of the respired $\mathrm{CO}_{2}$, sample exetainers were placed in a multiflow autosampler $(\mathrm{GV}$, Manchester, UK) coupled to a stable isotope ratio mass spectrometer (IRMS, ISOPRIME, GV). A gas sample of the respired $\mathrm{CO}_{2}$ of each exetainer was entrained in the carrier gas $\mathrm{He} . \mathrm{CO}_{2}$ was isolated via gas chromatography separation and, subsequently, carried to the mass spectrometer. At least every 10 samples, external standard gas samples of laboratory standard gas of 300 ppm $\mathrm{CO}_{2}$ (Messer, Griesheim, Germany) were measured to reconstruct any drift occurring over the measurement period. Using a linear regression of the standard gas values, the sample data was then re-calculated whenever the drift exceeded $0.05 \%$. Following the analysis, all exetainers were stored in a freezer until thallus water extractions took place.

\section{Thallus water extractions}

After assessing the lichens' respired $\mathrm{CO}_{2}$ isotopic composition, the same samples were processed to obtain the thallus water ${ }^{18} \mathrm{O}$ signal. The thallus water of each sample was extracted using cryogenic vacuum distillation. Each sample exetainer was opened and instantly placed into the extraction 
vessel of a vacuum line. The vessel was then immersed into liquid nitrogen to keep the sample frozen, attached to the vacuum line and evacuated. Subsequently, the vessel was heated up to $100^{\circ} \mathrm{C}$ and the vaporised water was collected into a cold finger. Once all moisture had been extracted from the sample, the cold finger was sealed under vacuum using a torch. The WC of each sample was determined by weighing the exetainers before and after water extraction. The RWC was then calculated as difference between the lichen's actual weight $V_{\mathrm{L}}$ and the weight of the dry lichen $V_{\text {dry }}$ divided by the difference between the wet weight $V_{\text {wet }}$ at maximum water content $\mathrm{WC}_{\max }$ (Beckett 1995). Since distillation yields the absolute dry weight, there might be a slight difference of about 10-20\% compared to conventionally observed dry weights achieved by drying at $60^{\circ} \mathrm{C}$ or with silica gel.

Isotopic analysis of extracted thallus water

Oxygen isotope ratios of the extracted water samples were determined by equilibration of water with $\mathrm{CO}_{2}$ (Epstein and Mayeda 1953). $200 \mu \mathrm{l}$ of the water sample was placed into a gastight vial. An aliquot of pure $\mathrm{CO}_{2}$ was added and was allowed to equilibrate for $16 \mathrm{~h}$ at a constant temperature of $17^{\circ} \mathrm{C}$ in a water bath. The equilibrated $\mathrm{CO}_{2}$ was then analysed for its oxygen isotopic composition using a multiflow autosampler coupled with an IRMS (ISOPRIME, GV).

All $\delta^{18} \mathrm{O}$ ratios are reported relative to VSMOW (Vienna Standard Mean Ocean Water). The measurements were taken against calibrated reference gas $\left(\mathrm{CO}_{2} 5.3\right.$, Linde AG, Pullach, Germany) cross-calibrated to ISO-TOP reference gas $\left(\mathrm{CO}_{2}\right.$, Messer), which in turn was cross-calibrated to IAEA-CH-4 and IAEA-CH-6 standards (International Atomic Energy Agency, Vienna, Austria).

\section{Results}

Morphological properties

All studied species revealed specific morphological architectures with structural variations summarised in Table 1. Generally, the rate of water exchange depends on both, the lichens' growth form as well as its specific internal morphological properties. Concerning growth form, C. arbuscula and $U$. filipendula are representatives of the commonly highly branched fruticose type, which typically reveal a high surface to volume ratio (Larson and Kershaw 1976). In contrast, $P$. caperata represents the lobated foliose growth form and also $C$. convoluta, even though it is classified as fruticose type, forms conspicuous and thick foliose-like thallus lobes. These leaf-like growth forms typically exhibit low surface to volume ratios. In accordance with these assumptions, the observed specific evaporation rates showed similar and faster progressions for the fruticose as compared to the foliose species (see Fig. 1b).

Regarding the internal stratification of the thallus, $P$. caperata and $U$. filipendula both possess an entirely enclosing outer cortex composed of conglutinated thickwalled hyphae (see cross-sections Table 1). In contrast, $C$. arbuscula does not have any outer cortex. Here, the algal and medullary layers are directly exposed to the surrounding air. C. convoluta only exhibits an upper but no lower cortex (Table 1). Both fruticose species furthermore reveal supporting structures of conglutinated hyphae inside the thallus. Despite these dense areas, all species showed algal and medullary layers of varying layer thickness composed of loosely associated hyphae with hydrophobic cells walls.

To receive a rough estimate of the proportional amount of lichen matrix directly exposed to air, the ratio of the outermost layers (cortex and algal layer) versus the internal thallus structures (medullary layer and/or central strand or cylinder, respectively) was calculated from the relative volume of the various thallus structures. Regarding this, about 51 and $29 \%$ of the matrix of the fruticose species $C$. arbuscula and $U$. filipendula, respectively, is located inside the thallus, and 49\% (C. arbuscula) and 71\% (U. filipendula) of the structures are directly exposed to the surrounding atmosphere. In contrast, the internal thallus structures of the foliose species $P$. caperata and $C$. convoluta amount to approximately 79 and $70 \%$ of total thallus thickness, respectively, whereas their exposed upper cortex and algal layer at the thallus surface comprises only $21 \%$ ( $P$. caperata) and $30 \%$ (C. convoluta).

Water relations of lichen species during the experiment

After full rehydration $P$. caperata and $C$. arbuscula showed higher $\mathrm{WC}_{\max }\left(V_{\text {wet }}\right)$ of approximately 2.25 and $2.60 \mathrm{~g}\left(\mathrm{H}_{2} \mathrm{O}\right) \mathrm{g}(\mathrm{DW})^{-1}$, respectively, as compared to $C$. convoluta and $U$. filipendula which only achieved about 1.45 and $1.20 \mathrm{~g}\left(\mathrm{H}_{2} \mathrm{O}\right) \mathrm{g}(\mathrm{DW})^{-1}$, respectively (Table 1). During exposure to the experimental conditions for $7 \mathrm{~h}$, the lichens dehydrated at varying rates down to $0.09 \pm 0.083 \mathrm{~g}\left(\mathrm{H}_{2} \mathrm{O}\right) \mathrm{g}(\mathrm{DW})^{-1}$ on average (Fig. 1a). Species-specific absolute evaporation rates (Fig. 1b) were calculated using numerical derivation of the WC data. In order to illustrate species-specific differences in dehydration extent and velocity, Fig. 1c presents the decline in RWC (\% water content relative to $\mathrm{WC}_{\max }$ ).

C. arbuscula showed the highest initial evaporation rate, loosing $95 \%$ of its total evaporated water within the first $3.5 \mathrm{~h}$ of the experiment. U. filipendula and $P$. caperata took approximately 5.5 and $6 \mathrm{~h}$ to evaporate $95 \%$ of their total water. In contrast, $C$. convoluta showed rather moderate but more continuous water loss throughout the course of the experiment and took $6.5 \mathrm{~h}$ to loose $95 \%$ of its total water. 

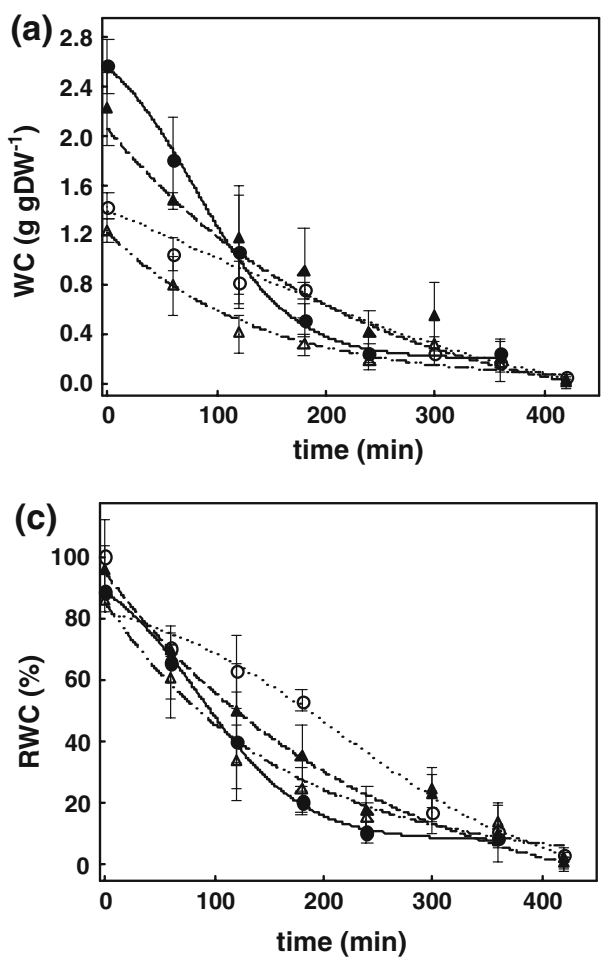

Fig. 1 Time course of the decrease in water content $\left(W C ; V_{\mathrm{L}}\right)$ expressed in $\mathrm{g}\left(\mathrm{H}_{2} \mathrm{O}\right) \mathrm{g}(\mathrm{DW})^{-1}$ (a) and in \% WC relative to $\mathrm{WC}_{\max }$ (RWC, c) of the four studied lichen species. b Mean absolute evaporation rates in $\mathrm{mg}\left(\mathrm{H}_{2} \mathrm{O}\right) \mathrm{g}(\mathrm{DW})^{-1} \mathrm{~min}^{-1}$ calculated from numerical derivation of $\mathrm{WC} ; V_{\mathrm{L}}(\mathbf{a})$. Open and closed triangles and open and closed circles represent $U$. filipendula, $P$. caperata,

However, the similar WC (and RWC) values of all species at the end of the experiment confirm the lichens physical equilibration with the environment. This indicates that, in terms of expected isotopic processes, the observed initial differences in evaporation rates may become irrelevant once the lichens equilibrate with the environmental conditions.

$\delta^{18} \mathrm{O}$ of thallus water during dehydration

During the course of the experiment, $\delta^{18} \mathrm{O}$ of the thallus water of all investigated lichen species showed progressive enrichment which lasted between 2.5 and $5 \mathrm{~h}$ (three e-folding times) depending on the investigated species. Following this enrichment period, the lichens approached a steady-state value (Fig. 2a). In general, $\delta^{18} \mathrm{O}$ values ranged from $-6.5 \pm 0.3 \%$ in water-saturated samples at the start of the desiccation event to in average $+1.2 \pm 1.2 \%$ when lichens had approached their maximal value.

Correlating RWC and thallus water $\delta^{18} \mathrm{O}$ confirmed a general progressive enrichment with decreasing $R W C$ in all studied lichens (Fig. 2b). Furthermore, the overall degree of $\delta^{18} \mathrm{O}$ shift also depended upon the lichen species: at the start of the experiment, in totally water-saturated samples $(90$ $100 \%$ RWC), $\delta^{18} \mathrm{O}$ of thallus water was similar between the
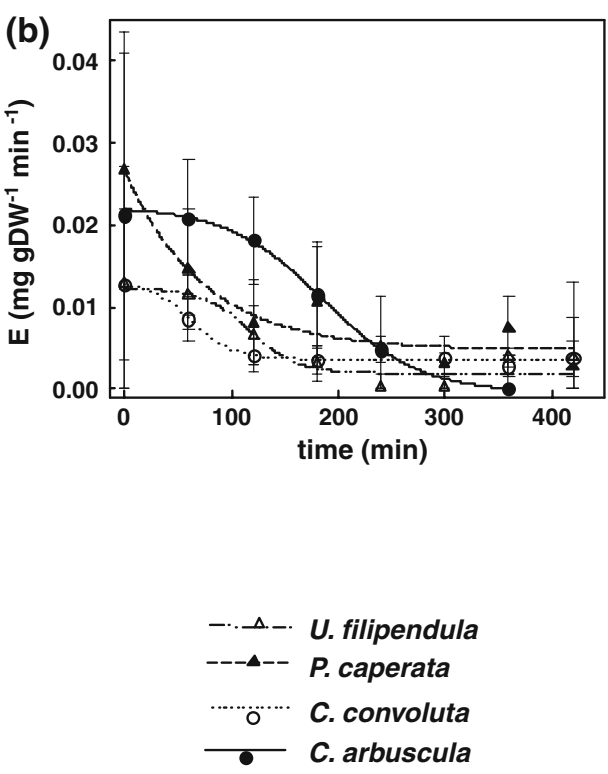

C. convoluta and C. arbuscula, respectively. Values at time 0 represent the averages of all investigated samples at water saturation $(n=31-44)$. All following values are the averages of samples analysed at each sampling time $(n=3-8)$. Error bars represent standard deviations. Introduced regressions (lines of best fit; all introduced regressions with $P<0.05$ ) serve to guide the eye

respective species starting about $1.5 \%$ more enriched compared to $\delta^{18} \mathrm{O}$ of the water source $(-8 \pm 0.5 \%)$. Cernusak et al. (2003) observed that leaves separated from the petiole lose about $8.5 \%$ of their water content within the first $2-3$ min after cutting and concluded that this leads to a bias in the leaf water isotopic analyses due to evaporative enrichment. For the present experiment, rehydrated lichen samples removed from the water were blotted and weighed before being placed into a sealed exetainer which required approx. 3-5 min. It is therefore inferred that the isotopic deviation of the water-saturated lichens' thallus water $\delta^{18} \mathrm{O}$ from that of the source water derives from strong initial evaporation during sample treatment.

At the end of the desiccation, at RWC below $30 \%$, the isotopic composition of the thallus water showed significant differences between the corticolous, more xeric species (U. filipendula and P. caperata) and the terricolous, more mesic species $(C$. arbuscula and $C$. convoluta; $t$ test: $t=4.7 ; \quad \mathrm{FG}=26: \quad P<0.0001) . \quad U . \quad$ filipendula and $P$. caperata showed a stronger $\delta^{18} \mathrm{O}$ enrichment of $8.4 \pm 1.1 \%$ (corresponding to a final absolute $\delta^{18} \mathrm{O}$ of $+1.9 \pm 1.1 \%$ ), whereas $C$. convoluta and $C$. arbuscula only achieved changes of $6.8 \pm 0.4 \%$ (corresponding to a final $\delta^{18} \mathrm{O}$ of $+0.3 \pm 0.4 \%$ ) during dehydration. 

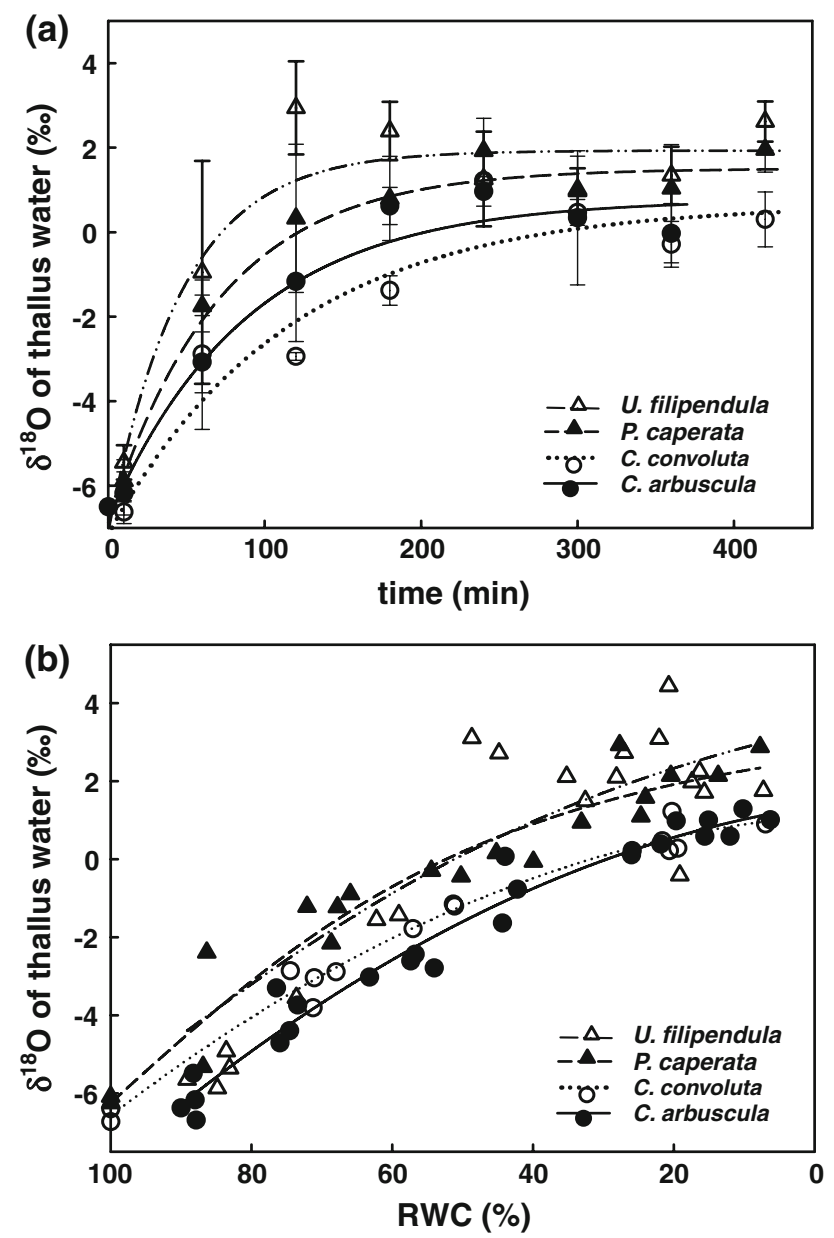

Fig. 2 Time course of $\delta^{18} \mathrm{O}$ of thallus water (a) and thallus water $\delta^{18} \mathrm{O}$ as a function of relative water content (b, RWC) during dehydration of the four studied lichen species. Open and closed triangles and open and closed circles represent $U$. filipendula, $P$. caperata, $C$. convoluta and $C$. arbuscula, respectively. a The values represent averages of samples analysed at each sampling time, $n=3-8$. Error bars represent standard deviations and regressions follow an exponential fit. b Single values of analysed samples (P. caperata: $n=19$, C. convoluta: $n=14$, C. arbuscula: $n=24$ and $U$. filipendula: $n=20$, respectively) are fitted with non-linear regressions calculated from 'Smith-functions' (Tenhunen et al. 1976). (All regressions: $P<0.0001$ )

Comparing $\delta^{18} \mathrm{O}$ of thallus water and respired $\mathrm{CO}_{2}$

In addition, $\delta^{18} \mathrm{O}$ of the thallus water was recalculated and expressed as $\delta^{18} \mathrm{O}$ of $\mathrm{CO}_{2}$ in isotopic equilibrium with water, and compared to observed $\delta^{18} \mathrm{O}$ of respired $\mathrm{CO}_{2}$ (Fig. 3). On assuming homogeneous thallus water isotopic composition and complete equilibration between the thallus water and respired $\mathrm{CO}_{2}$, all data points should fall along the $1: 1$ equilibrium line. Indeed, all species reveal $\delta^{18} \mathrm{O}$ values inclining parallel to the potential equilibrium line, but with an offset of about $1.2 \%$ indicating more enriched $\mathrm{CO}^{18} \mathrm{O}$ compared to $\mathrm{H}_{2}{ }^{18} \mathrm{O}$ values. This apparent offset may be related to the existence of various, isotopically

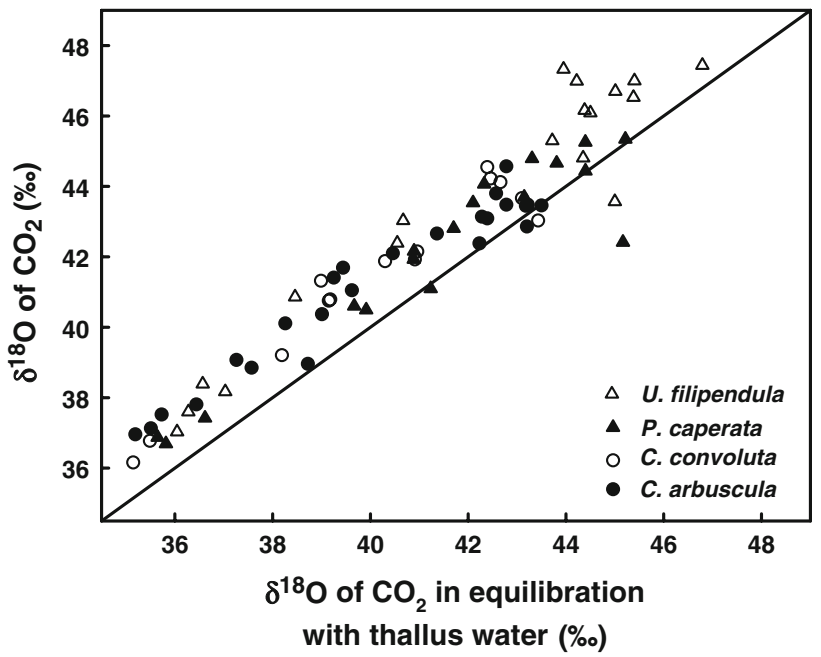

Fig. 3 Correlation between measured $\delta^{18} \mathrm{O}$ of respired $\mathrm{CO}_{2}$ and theoretical values of $\mathrm{CO}_{2}$ in isotopic equilibrium with the thallus water of all studied lichen species. The 1:1 line indicates $100 \%$ equilibration between $\mathrm{CO}_{2}$ and thallus water. Open and closed triangles and open and closed circles represent $U$. filipendula $(n=18), P$. caperata $(n=18), C$. convoluta $(n=14)$ and $C$. arbuscula $(n=24)$, respectively. Note that more enriched $\delta^{18} \mathrm{O}$ values in general also signify samples with low RWC

distinct water pools within the thallus. This is also hinted at the end of the desiccation period where both observed and equilibrated $\mathrm{CO}_{2}$ appear to come to the same isotopic value. However, at this point of sampling $\delta^{18} \mathrm{O}-\mathrm{CO}_{2}$ values showed large scatter, possibly due to low CA activity resulting from low thallus RWC (below 20-30\%).

\section{Discussion}

The single-source model

Comparing the measured lichen thallus water isotopic compositions with the predictions of Helliker and Griffiths' single-source model (2007), the model (dotted lines, Fig. 4) overestimates thallus water compositions by far, especially at the end of the curve. This can be explained by the fact that the relative humidity in the box constantly decreases and $R_{\mathrm{M}}$ deviates further and further from the equilibrium isotopic composition $R_{\text {eq }}$. For example, at $h_{\mathrm{s}}=0.7, \delta_{\mathrm{M}}$ is already $11 \%$ (with $\delta_{\mathrm{a}}=-16 \%$ ) and constantly increases with decreasing humidity $h_{\mathrm{s}}$. Obviously, the isotopic signal of lichen thallus water does not follow Helliker and Griffiths' approach but rather tends to "constantly" equilibrate with water vapour.

The $\Psi$ model

Helliker and Griffiths (2007) assume water vapour at the evaporating site to be at $100 \%$ relative humidity, i.e. at 

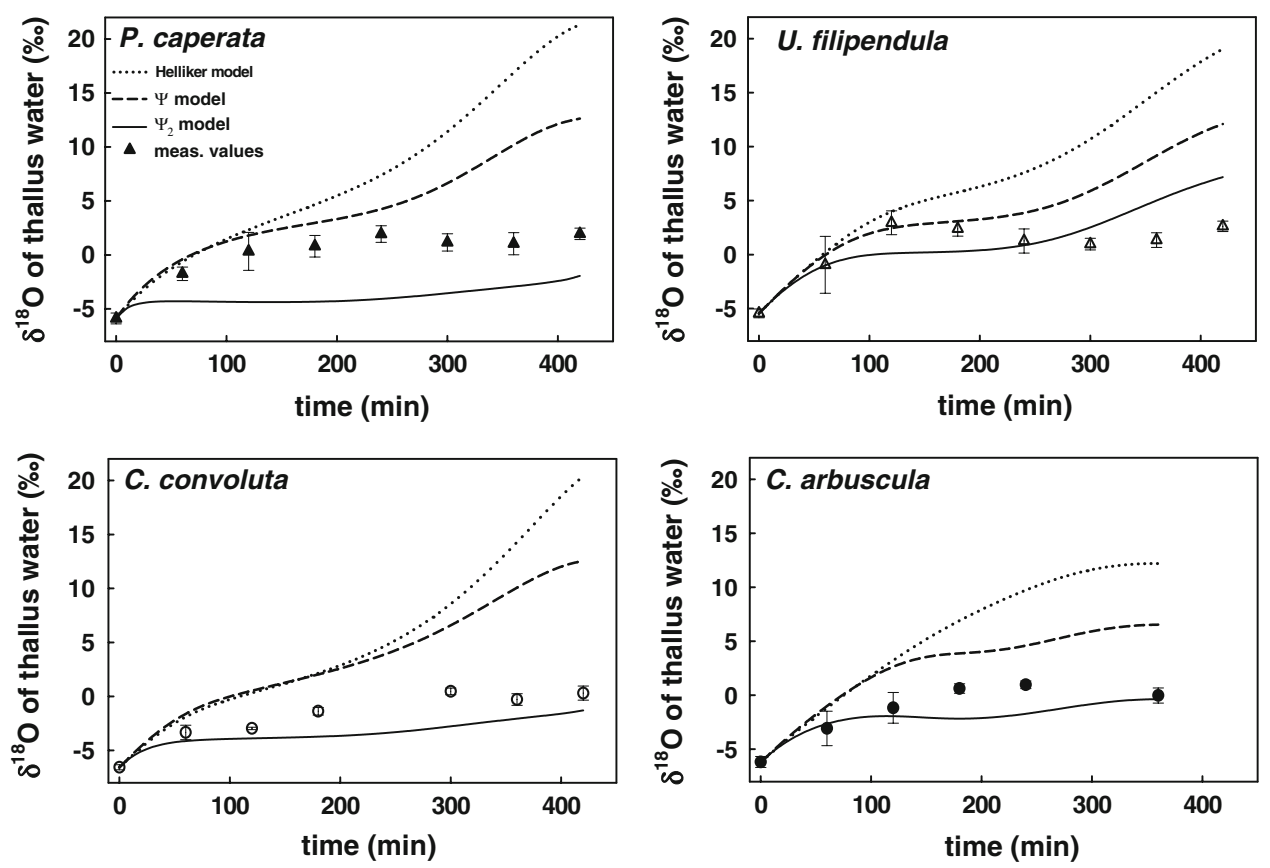

Fig. 4 Comparison of experimentally measured time course of $\delta^{18} \mathrm{O}$ of thallus water (symbols) and modelled values calculated from three distinct model approaches (lines) for the four investigated green-algal lichen species. Dotted lines represent values calculated from the Helliker and Griffiths approach (2007), dashed lines represent values calculated from a modified approach taking into account the lichens'

varying water potential and solid lines are derived from a model approach additionally incorporating the existence of two isotopically distinct water pools (see text for further information). Measured values are averages of samples analysed at each sampling time, $n=3-8$ (see Fig. 2a). Error bars represent standard deviations

$h_{\mathrm{L}}=\frac{w_{\mathrm{a}}}{h_{\mathrm{i}} w_{\mathrm{sat}}\left(T_{\mathrm{L}}\right)}=\frac{h_{\mathrm{s}}}{h_{\mathrm{i}}}$,

saturation water mole fraction at leaf temperature: $w_{\text {sat }}\left(T_{\mathrm{L}}\right)$. This assumption might be true for vascular plants where stomata actively regulate water conditions. In lichens, however, evaporation varies passively depending on surrounding conditions and prevailing water status. Hence, during desiccation, thallus water potential $\Psi$ rapidly drops below that of pure water and approaches prevailing environmental conditions (e.g. Lange et al. 2001; Jonsson et al. 2008). Depending on the magnitude of any preceding shifts in environmental conditions as well as on specific morphological properties of the lichen species (cf. Blum 1973; Rundel 1988), the duration of these re-adjustments of thallus water potential with ambient conditions may range from several minutes up to a few hours (Nash 1996). Thus, particularly at constant and/or slowly changing surrounding conditions thallus water potential can be assumed to be in equilibrium with the atmosphere. Water potential is monotonically linked to relative humidity by the Kelvin equation (Rawlins 1972):

$h_{\mathrm{i}}=\exp \left\{\frac{V_{\mathrm{w}} \Psi}{\Re T}\right\}$,

with the molar water concentration $V_{\mathrm{w}}=18.048 \times$ $10^{-6} \mathrm{~m}^{3} \mathrm{~mol}\left(\mathrm{H}_{2} \mathrm{O}\right)^{-1}$ and the gas constant $\Re=8.314 \mathrm{~J}$ $(\mathrm{K} \mathrm{mol})^{-1}$. Based on this, relative humidity $h_{\mathrm{s}}$ in Eq. 2 should be replaced by $h_{\mathrm{L}}$ :

where $h_{\mathrm{i}}$ is calculated from the Kelvin equation (Eq. 3) with the lichens actual thallus water potential. As the thallus water potential approaches environmental conditions, the corrected relative humidity $h_{\mathrm{L}}$ approaches unity. Accordingly, the lichen water isotopic composition approaches equilibrium with the atmosphere, $R_{\text {eq }}$ (cf. Eq. 2).

This indicates that for the understanding of this process, the lichens water potential has to be known. Because water potential could not be measured within the present study, it is estimated from RWC of representative mesic and xeric lichens (Beckett 1995). The relation between RWC and thallus water potential $\Psi$ is termed pressure-volume curve ( $P V$-curve), i.e. $-1 / \Psi$ as a function of $1-$ RWC (Tyree and Jarvis 1981). For the present study, exponential functions of $\Psi$ in relation to RWC were fitted (Fig. 5) to literature data of (1) C. convoluta (Proctor et al. 1998) for the two mesic species $C$. convoluta and C. arbuscula and of (2) $R$. montagnei (Beckett 1995) for the two xeric species $U$. filipendula and $P$. caperata. Since the $P V$-curves were only measured at relatively high RWC, the lower ranges of the relationships are uncertain extrapolations. Also, the dry weight, $V_{\text {dry }}$, was measured after vacuum distillation and is 


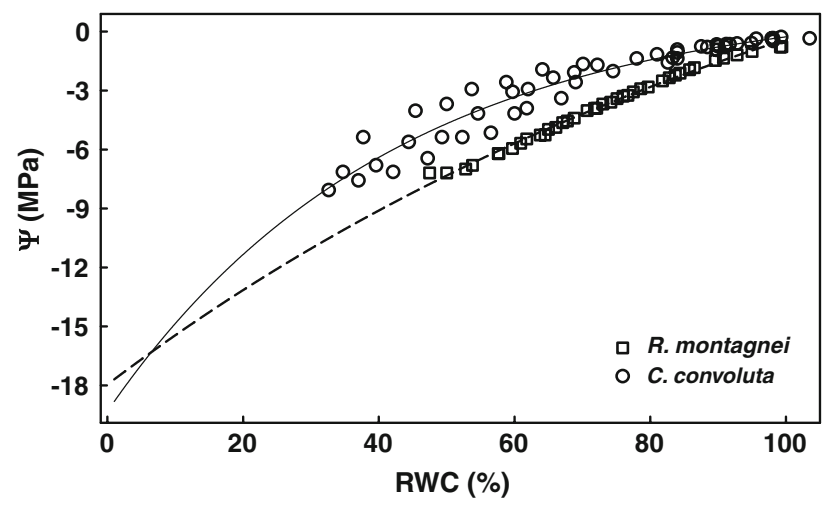

Fig. 5 Literature data of the relationship between RWC and thallus water potential $\Psi$ (pressure-volume curve; $P V$-curve) of $R$. montagnei (Beckett 1995) and C. convoluta (Proctor et al. 1998). Lines represent exponential functions fitted for each set of literature data

10-20\% lower than conventionally assessed dry weight measured after drying at $60^{\circ} \mathrm{C}$ or over silica gel. These results in higher apparent RWC of the lichens in the present experiment compared to literature $P V$-curves. Ideally, species-specific RWC and $\Psi$ should be measured as the experiment is conducted.

The modelled values of this so-called ' $\Psi$ model' (dashed lines, Fig. 4) correlate closer to the measurements but are still significantly different, especially during the second half of the experiment. This may have different reasons which will be discussed in the following. One possibility may simply be the adoption of erroneous $P V$-curves. If, with decreasing RWC, thallus $\Psi$ descends faster than suggested by our exponential fit, relative humidity $h_{\mathrm{L}}$ would have already approached unity which would result in equilibration between lichen thallus water and atmospheric vapour.

Another reason may be the estimation of the vapour isotopic composition inside the box that was not measured but calculated. Water vapour leaves the box via a perforated lid which was calculated without a fractionation for diffusion through the lid because of the fairly large holes (cf. Appendix 2). However, fractionation at the box top is quite likely and therefore its relevancy was tested with the maximum diffusional fractionation (32\%, Cappa et al. 2003). Although this altered the time courses, it did not change the general picture as shown exemplarily for $U$. filipendula (Fig. 6): integrating fractionation at the box top yielded faster increase of the lichen isotopic composition at the beginning of the experiment and even higher endpoints.

Since the box was not ventilated due to the fragile nature of lichens, a third possibility may be the existence of a large gradient in box relative humidity. Relative humidity was measured at the top of the box. Thus a gradient from high relative humidity near the evaporating lichens to low relative humidity near the box top may result in discrepancies between actual and measured relative humidity conditions.

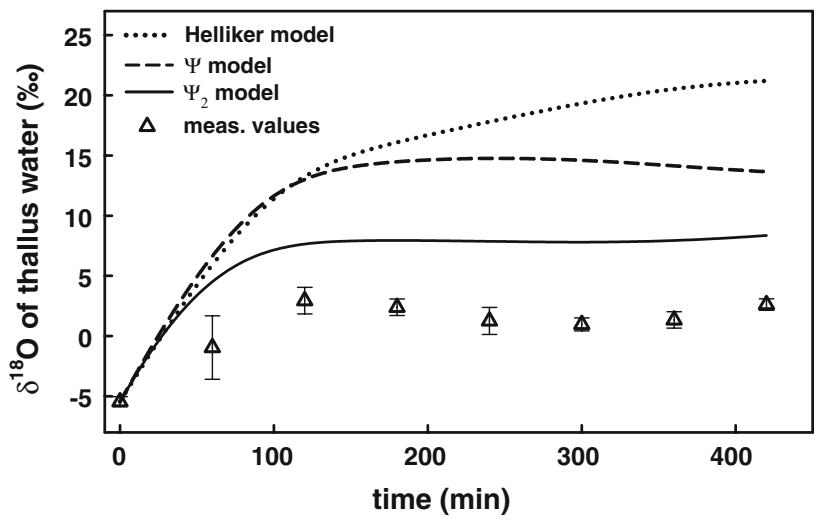

Fig. 6 Integration of an isotopic fractionation at the box top (32\%, Cappa et al. 2003) into the three distinct model approaches (see Fig. 4). As in Fig. 4, the graph illustrates the comparison of experimentally measured time course of $\delta^{18} \mathrm{O}$ of thallus water (symbols) and the modelled values from the three model approaches, respectively. Data are for the exposed growing fruticose lichen U. filipendula

However, this difference should decrease with time because of very low evaporation rates at the end of the experiment and probably does not explain the high end values.

The $\Psi_{2}$ model

Another possibility to improve the water exchange model could be a water compartmentation within the lichen thallus, as indicated by the $\delta^{18} \mathrm{O}-\mathrm{CO}_{2}$ observations (Fig. 3). Assuming isotopic equilibration between thallus water and respired $\mathrm{CO}_{2}$, given the prevailing conditions, the $\delta^{18} \mathrm{O}-$ $\mathrm{CO}_{2}$ of recalculated bulk thallus water should be similar to the measured respiratory $\delta^{18} \mathrm{O}-\mathrm{CO}_{2}$ at metabolic activity. The observed offset of approximately $1.2 \%$, indicating differing $\delta^{18} \mathrm{O}-\mathrm{CO}_{2}$ compared to bulk water over a broad range of water content, points to distinct water pools within the thallus, which may be related to the specificity of this structure. Lichens exhibit distinct morphological structures that differ in gas exchange, water holding capacity and water conductance depending on structure density (and cell wall thickness) (Blum 1973; Rundel 1988). In addition lichen's specific stratification causes these distinct structures to be more or less exposed to the atmosphere and hence to direct evaporation. In this respect, the dense layers of thick-walled, conglutinated hyphae (e.g. of the inner cylinder of $C$. arbuscula and central strand of $U$. filipendula) are not directly exposed to the surrounding atmosphere and have high water storage and retention ability with low water conductance (cf. Goebel 1926; Jahns 1984; Büdel and Scheidegger 1996). On the other hand, the outer cortices and the algal layer are in direct contact and rapidly exchange with the surrounding atmosphere (cf. Goebel 1926; Scheidegger 1994; Honegger 1995, 1996). Accordingly, water evaporates from these exposed regions (pool 1) 
while water from the inner regions (pool 2) serves as a 'storage pool' connected to the outer regions. This means that pool 1 evaporates, and exchanges water and water isotopes with both, pool 2 and the atmosphere, while pool 2 only exchanges water and water isotopes with pool 1, but not directly with the atmosphere. As an estimate of the proportion of thallus water directly exposed to air, the species-specific ratio of the exposed outer layer versus the internally located structures was used. Both were calculated from the relative area of the various thallus layers (Table 1). Then lichen water isotopic composition in two pools connected with each other was modelled. This leads to two coupled ordinary differential equations that were solved numerically (cf. Appendix 3):

$V_{\mathrm{L} 1} \frac{\mathrm{d} R_{\mathrm{L} 1}}{\mathrm{~d} t}=-R_{\mathrm{E}} E-\frac{R_{\mathrm{L} 1} V_{\mathrm{L} 1}+R_{\mathrm{L} 2} V_{\mathrm{L} 2}}{V_{\mathrm{L}}} E+k_{\mathrm{ex}}\left(R_{\mathrm{L} 2}-R_{\mathrm{L} 1}\right)$

$V_{\mathrm{L} 2} \frac{\mathrm{d} R_{\mathrm{L} 2}}{\mathrm{~d} t}=-k_{\mathrm{ex}}\left(R_{\mathrm{L} 2}-R_{\mathrm{L} 1}\right)$

where $R_{\mathrm{L} 1}$ and $R_{\mathrm{L} 2}$ denote the isotopic compositions in the two pools with size $V_{\mathrm{L} 1}$ and $V_{\mathrm{L} 2}$, respectively, and $k_{\mathrm{ex}}$ is a hypothetical exchange coefficient that allows exchange between the isotopic compositions of pools 1 and 2 . The first term on the right-hand side of Eq. 5 represents the change in isotopic composition due to evaporation. The second term represents the change due to the mixing of water of pool 1 with water coming from pool 2 , and the last term represents diffusional exchange. The isotopic composition of pool 2 (Eq. 6) is only changing due to diffusional exchange because any advective flux leaving pool 2 does not change its isotopic composition. In the following, this approach will be referred to as the ' $\Psi_{2}$ model'. In accordance with the previously found low water conductance in conglutinated thallus areas (cf. Goebel 1926; Jahns 1984; Büdel and Scheidegger 1996), a very low isotopic exchange coefficient $k_{\mathrm{ex}}$ between the two water pools leads to satisfactory results (solid lines, Fig. 4). This means that the storage pool remains basically at its initial value while the exchange pool is similar to the earlier $\Psi$ model. Together, this leads to a decrease of the modelled isotopic composition compared to the earlier $\Psi$ model. Figure 7 shows again exemplary results for $U$. filipendula, where one can see the fast reaction of the exchange pool and the slow storage pool. The observations of $\delta^{18} \mathrm{O}-\mathrm{CO}_{2}$ hint that the two water pools converge at the end of the experiment, which is not the case in the $\Psi_{2}$ model with the chosen exchange coefficient. However, the $\Psi_{2}$ model should be seen as a proof of concept not only because of the aforementioned missing information pieces in the experiment, but also because of the great complexity of water diffusion and evaporation processes taking place

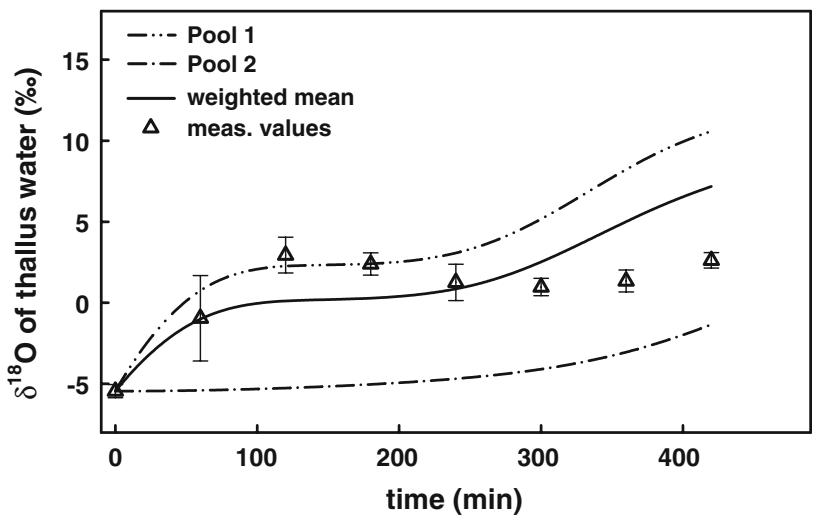

Fig. 7 The $\Psi_{2}$ model incorporates the existence of two isotopically distinct water pools connected with each other (see Fig. 4, dashed lines). The graph illustrates the experimentally measured time course of $\delta^{18} \mathrm{O}$ of thallus water (symbols) and the modelled values of the exposed, rapidly exchanging pool 1 , the internally located, slowly exchanging pool 2 , and the species-specifically weighted mean of both (see text for detailed information). Data are for the exposed growing fruticose lichen $U$. filipendula

during progressive dehydration that has not been taken into account (cf. Appendix 3), and because of the unknown nature of the isotopic exchange between the different thallus structures.

In summary it can be said that, considering our modelling results the study shows first appropriate steps towards a better understanding of oxygen isotope processes of lichens during water exchange. Nevertheless, single aspects remain open that have to be affirmed conclusively. The results of the dehydration experiment turned out to be somewhat ambiguous. The lichens' fragile nature created rather tricky experimental conditions. For example, the air inside the chamber could not be circulated effectively, which probably caused an inhomogeneous distribution of air moisture and water isotopes within the chamber. In addition, relevant parameters such as air moisture isotope composition and thallus water potential could not be measured. As a result, some of the input parameters of the model had to be determined indirectly. At that, the experimental approach pointed out that the aforementioned, imperative parameters need to be assessed in future studies. Continuous recording of these essential factors will then enable a precise survey and a more accurate assessment of the identified crucial mechanisms. Ultimately, detailed understanding will allow the transfer of these results to similar systems. Our results suggest that the proposed modelling approach may be applied to other nonvascular organisms such as bryophytes, terrestrial algae and cyanobacteria. Moreover, the rapid equilibration process indicates the potential value of lichens to be used as natural tracer for ambient vapour isotopic composition. Particularly their universal distribution, not only on a 
global scale but also within single ecosystems, points out the practicability of this approach.

\section{Conclusions}

A novel isotope enrichment model was demonstrated that can be used to explain oxygen isotope processes taking place in green-algal lichens subject to progressive dehydration. This model takes into account the specific poikilohydric nature of these cryptogams. As such, the water status as well as the thallus water potential of these organisms constantly varies along with surrounding conditions. Accordingly, it could be shown that their remaining thallus water rapidly equilibrates isotopically with surrounding atmospheric vapour. This is in contrast to vascular, homoiohydric plants, where leaf water is generally isotopically enriched compared to that in equilibrium with ambient water vapour.

Whereas previous studies have shown the suitability of stable carbon isotopes of poikilohydric cryptogams to serve as, e.g. long-term tracers for carbon acquisition, environmental change of $\mathrm{CO}_{2}$ sources and global change (Máguas and Brugnoli 1996; Lakatos et al. 2007), or as paleo- $\mathrm{CO}_{2}$ proxies (Fletcher et al. 2005), to date no work has focussed on the ability of oxygen stable isotope ratios of poikilohydric organisms to function as long-term indicator of water sources. Considering that the ${ }^{18} \mathrm{O}$ signal of plant organic material of $T$. usneoides may be used to reconstruct the isotope ratio of atmospheric water for large spatial and temporal scales (Helliker and Griffiths 2007), and preeminently in view of the here presented results, poikilohydric epiphytes may serve as prospective long-term proxies for different environmental water sources.

Acknowledgments We are particularly thankful to the stable isotope laboratory of Christiane Werner (University Bielefeld) which provided for parts of the isotopic analysis. We thank Howard Griffiths (University Cambridge) for scientific support and discussions. In addition, several people helped to conduct the laboratory studies. Special thanks to Rodrigo Maia (University Lisbon), Barbara Teichner (University Bielefeld), Beatrix Weber and Silvia Kühner (University Kaiserslautern), for their assistance. M.L. was granted in the frame of the ECprogram NETCARB (HPRN-CT-1999-59) and of the ESF-program SIBAE (62561 EXGC EX03). B.H., C.M. and M.L. were supported by the PPP project of DAAD/GRICES (D/04/42019) and the Portuguese Science Foundation, FCT (POCTI/BIA-BDE/60140/2004).

\section{Appendix}

Appendix 1: The Helliker and Griffith (2007) leaf water isotope model for non-vascular plants

The derivation of the Helliker and Griffiths (2007) model is very similar to the Farquhar and Cernusak (2005) non- steady state model of leaf water enrichment in vascular plants. However, both Helliker and Griffiths (2007) and Farquhar and Cernusak (2005) derive an ordinary differential equation that they then solve numerically. The differential equation of Helliker and Griffiths (2007) is solved iteratively here, as described for example in Cuntz et al. (2007), which gives insights into the characteristics of the Helliker and Griffiths (2007) model.

Be $V_{\mathrm{L}}$ lichen water content with the isotopic signature $R_{\mathrm{L}}$ and the temperature $T_{\mathrm{L}}$. Outside air humidity $h_{\mathrm{a}}$ has a mole fraction $w_{\mathrm{a}}$, which is the vapour partial pressure $e_{\mathrm{a}}$ divided by atmospheric pressure $P: w_{\mathrm{a}}=e_{\mathrm{a}} / P$. The lichen water balance is thus

$$
\begin{aligned}
\frac{\mathrm{d} V_{\mathrm{L}}}{\mathrm{d} t} & =-E \\
& =-g_{\mathrm{t}}\left[w_{\text {sat }}\left(T_{\mathrm{L}}\right)-w_{\mathrm{a}}\right]
\end{aligned}
$$

with $w_{\text {sat }}\left(T_{\mathrm{L}}\right)$ the saturation mole fraction at lichen temperature $T_{\mathrm{L}}, g_{\mathrm{t}}$ the (unknown) conductance from the lichen water reservoir to the atmosphere and $E$ the transpiration of the lichen. This is valid for drying conditions. Rain in this picture gets simply mixed into the bucket: $V_{\mathrm{L}, \text { new }}=V_{\mathrm{L}, \text { old }}+$ rain; $R_{\mathrm{L} \text {,new }}=\left(V_{\mathrm{L} \text {,old }} \times R_{\mathrm{L} \text {,old }}+\operatorname{rain} \times R_{\text {rain }}\right) /\left(V_{\mathrm{L} \text {,old }}+\right.$ rain $)$.

The isotopic water balance (at transpiration) is then

$$
\begin{aligned}
& \frac{\mathrm{d}\left(R_{\mathrm{L}} V_{\mathrm{L}}\right)}{\mathrm{d} t}=-R_{\mathrm{E}} E \\
& V_{\mathrm{L}} \frac{\mathrm{d} R_{\mathrm{L}}}{\mathrm{d} t}+R_{\mathrm{L}} \frac{\mathrm{d} V_{\mathrm{L}}}{\mathrm{d} t}=-\frac{g_{\mathrm{t}}}{\alpha_{\mathrm{k}}}\left[\frac{1}{\alpha^{+}} R_{\mathrm{L}} w_{\mathrm{sat}}\left(T_{\mathrm{L}}\right)-R_{\mathrm{a}} w_{\mathrm{a}}\right]
\end{aligned}
$$

with $R_{\mathrm{a}}$ being the isotopic composition of ambient vapour, $\alpha_{\mathrm{k}}$ the kinetic fractionation and $\alpha^{+}$the vapour-liquid water equilibrium fractionation $(\alpha>1)$.

Inserting Eq. 7 in Eq. 8 gives

$$
\begin{aligned}
V_{\mathrm{L}} \frac{\mathrm{d} R_{\mathrm{L}}}{\mathrm{d} t}+R_{\mathrm{L}} \frac{\mathrm{d} V_{\mathrm{L}}}{\mathrm{d} t}= & -\frac{1}{\alpha_{\mathrm{k}}} \frac{-\frac{\mathrm{d} V_{\mathrm{L}}}{\mathrm{d} t}}{w_{\mathrm{s}}\left(T_{\mathrm{L}}\right)-w_{\mathrm{a}}} \\
& \times\left[\frac{1}{\alpha^{+}} R_{\mathrm{L}} w_{\mathrm{sat}}\left(T_{\mathrm{L}}\right)-R_{\mathrm{a}} w_{\mathrm{a}}\right] .
\end{aligned}
$$

If one replaces $\frac{\mathrm{d} V_{\mathrm{L}}}{\mathrm{d} t}=-E$ and defines $h_{\mathrm{s}} \equiv \frac{w_{\mathrm{a}}}{w_{\text {sat }}\left(T_{\mathrm{L}}\right)}$, this yields

$$
\begin{gathered}
V_{\mathrm{L}} \frac{\mathrm{d} R_{\mathrm{L}}}{\mathrm{d} t}-E R_{\mathrm{L}}=-\frac{1}{\alpha_{\mathrm{k}}} \frac{E}{1-h_{\mathrm{s}}}\left[\frac{1}{\alpha^{+}} R_{\mathrm{L}}-R_{\mathrm{a}} h_{\mathrm{s}}\right] \\
\frac{\mathrm{d} R_{\mathrm{L}}}{\mathrm{d} t}=-\frac{1}{\alpha_{\mathrm{k}} \alpha^{+}} \frac{E}{V_{\mathrm{L}}\left(1-h_{\mathrm{s}}\right)} R_{\mathrm{L}}+\frac{E R_{\mathrm{a}} h_{\mathrm{s}}}{\alpha_{\mathrm{k}} V_{\mathrm{L}}\left(1-h_{\mathrm{s}}\right)}+\frac{E}{V_{\mathrm{L}}} R_{\mathrm{L}} \\
=\left[1-\frac{1}{\alpha_{\mathrm{k}} \alpha^{+}\left(1-h_{\mathrm{s}}\right)}\right] \frac{E}{V_{\mathrm{L}}} R_{\mathrm{L}}+\frac{1}{\alpha_{\mathrm{k}}} \frac{h_{\mathrm{s}}}{1-h_{\mathrm{s}}} \frac{E}{V_{\mathrm{L}}} R_{\mathrm{a}}
\end{gathered}
$$

which can be written as

$\frac{\mathrm{d} R_{\mathrm{L}}}{\mathrm{d} t}=k_{1} R_{\mathrm{L}}+k_{2}$,

with $k_{1}=\left[1-\frac{1}{\alpha_{\mathrm{k}} \alpha^{+}\left(1-h_{\mathrm{s}}\right)}\right] \frac{E}{V_{\mathrm{L}}}$ and $k_{2}=\frac{1}{\alpha_{\mathrm{k}}} \frac{h_{\mathrm{s}} E}{1-h_{\mathrm{s}} V_{\mathrm{L}}} R_{\mathrm{a}}$. 
This functional form is the same in Helliker and Griffiths (2007) and in Farquhar and Cernusak (2005) with different $k_{1}$ and $k_{2}$. One can simply solve this ordinary differential equation (ODE) numerically or solve it iteratively. The latter means if the time step is sufficiently small, one can assume stable, constant outside conditions and then the ODE can be solved analytically. The general solution to the ODE of Eq. 11 is

$R_{\mathrm{L}}=a+b \exp (c t)$.

Calling $R_{0}$ the isotopic composition of lichen water at time 0: $R_{0}=R_{\mathrm{L}}(t=0)$, this gives

$a=-\frac{k_{2}}{k_{1}}=R_{\mathrm{M}} ; b=R_{0}+\frac{k_{2}}{k_{1}}=R_{0}-R_{\mathrm{M}}$;

$c=k_{1}=-\left[\frac{1}{\alpha_{\mathrm{k}} \alpha^{+}\left(1-h_{\mathrm{s}}\right)}-1\right] \frac{E}{V_{\mathrm{L}}}$.

And so

$$
\begin{aligned}
R_{\mathrm{L}} & =R_{\mathrm{M}}+\left[R_{0}-R_{\mathrm{M}}\right] \exp \left\{-\left[\frac{1}{\alpha_{\mathrm{k}} \alpha^{+}\left(1-h_{\mathrm{s}}\right)}-1\right] \frac{E}{V_{\mathrm{L}}} t\right\} \\
& \approx R_{\mathrm{M}}+\left[R_{0}-R_{\mathrm{M}}\right] \exp \left\{-\frac{h_{\mathrm{s}}}{1-h_{\mathrm{s}}} \frac{E}{V_{\mathrm{L}}} t\right\}
\end{aligned}
$$

where $R_{\mathrm{M}}$ was defined as

$R_{\mathrm{M}} \equiv \frac{\alpha^{+} h_{\mathrm{s}} R_{\mathrm{a}}}{1-\alpha_{\mathrm{k}} \alpha^{+}\left(1-h_{\mathrm{s}}\right)}$,

exactly as Farquhar and Gan (2003) [cf. also Eq. 10 of Helliker and Griffiths (2007)]. The lichen water therefore tends towards a maximum value $R_{\mathrm{M}}$. At very humid conditions $h_{\mathrm{s}}=1, R_{\mathrm{M}}=\alpha^{+} R_{\mathrm{a}}$, i.e. lichen water isotopically equilibrates with air vapour, as stated by Helliker and Griffiths (2007) [their Eq. 11].

The lichen water tends towards the maximum value $R_{\mathrm{M}}$ with a time constant. With $\alpha_{\mathrm{k}} \approx 1$ and $\alpha^{+} \approx 1$, this gives $\tau \approx V_{\mathrm{L}} / g_{t} w_{\mathrm{a}}$, with $g_{\mathrm{t}} w_{\mathrm{a}}$ being the one-way flux from the atmosphere into the lichen. This is exactly opposite to homoiohydric vascular plants where the turnover time is determined by the one-way flux from the leaf to the atmosphere: $g_{\mathrm{t}} w_{\text {sat }}\left(T_{\mathrm{L}}\right)$ (Farquhar and Cernusak 2005).

Appendix 2: Calculation of the box water vapour isotopic composition

Box vapour isotopic composition could not be measured. So the isotopic composition is calculated assuming isotopic steady state and rapid mixing within the box. The former is justified because it takes about $1 \mathrm{~min}$ to reach isotopic steady state in the box. The latter is not valid in principal but the lichens were randomly distributed in three dimensions in the box and so it is rather difficult to know the exact humidity at all places. In steady state, the isotopic evaporation flux is balanced by the net isotope flux through the lid:

$R_{E} E=\frac{1}{\alpha_{\mathrm{ab}}}\left(R_{\mathrm{b}} J_{\text {out }}-R_{\mathrm{a}} J_{\mathrm{i} n}\right)$,

with $R_{\mathrm{E}}$ the isotopic composition of the evaporating flux $E$ of the lichens, $R_{\mathrm{b}}$ the isotopic composition of the vapour in the box, $R_{\mathrm{a}}$, the isotopic composition of the vapour surrounding the box, and $J_{\text {in }}$ and $J_{\text {out }}$ the two-one-way fluxes to and from the box. $\alpha_{a b}(>1)$ is thereby a possible fractionation during diffusion through the holes in the lid. Let $w_{\mathrm{b}}, w_{\mathrm{a}}$, and $w_{\mathrm{L}}$ be the water vapour mole fractions in the box, in the surrounding air and in the lichen, respectively. $w_{\mathrm{L}}$ is for example $w_{\mathrm{sat}}\left(T_{\mathrm{L}}\right)$ in the case of Helliker and Griffiths (2007). Together with Eq. 8 this can be rewritten as

$$
\begin{aligned}
& \frac{1}{\alpha_{\mathrm{k}}\left(w_{\mathrm{L}}-w_{\mathrm{b}}\right)}\left(\frac{R_{\mathrm{L}}}{\alpha^{+}} w_{\mathrm{L}}-R_{\mathrm{b}} w_{\mathrm{b}}\right) E \\
& \quad=\frac{1}{\alpha_{\mathrm{ab}}} R_{\mathrm{b}} \frac{w_{\mathrm{b}}}{w_{\mathrm{b}}-w_{\mathrm{a}}} E-\frac{1}{\alpha_{\mathrm{ab}}} R_{\mathrm{a}} \frac{w_{\mathrm{a}}}{w_{\mathrm{b}}-w_{\mathrm{a}}} E,
\end{aligned}
$$

which rearranges to

$R_{\mathrm{b}}=\frac{\frac{R_{\mathrm{L}} w_{\mathrm{L}}}{\alpha^{+} w_{\mathrm{b}}}\left(w_{\mathrm{b}}-w_{\mathrm{a}}\right)+R_{\mathrm{a}} \frac{\alpha_{\mathrm{k}} w_{\mathrm{a}}}{\alpha_{\mathrm{a}} w_{\mathrm{b}}}\left(w_{\mathrm{L}}-w_{\mathrm{b}}\right)}{\left(w_{\mathrm{b}}-w_{\mathrm{a}}\right)+\frac{\alpha_{\mathrm{k}}}{\alpha_{\mathrm{ab}}}\left(w_{\mathrm{L}}-w_{\mathrm{b}}\right)}$.

So the isotopic composition in the box $R_{\mathrm{b}}$ becomes simply $R_{\mathrm{a}}$ when the box humidity tends towards outside air humidity $w_{\mathrm{b}}=w_{\mathrm{a}}$, i.e. at the end of the experiment.

$w_{\mathrm{a}}$ and $R_{\mathrm{a}}$ in the derivation of the Helliker and Griffiths (2007) model, can now be replaced by $w_{\mathrm{b}}$ and $R_{\mathrm{b}}$. This leads to the same form of the ordinary differential equation (11) with different $k_{1}$ and $k_{2}$. Because the box tends towards outside air conditions for moisture and its isotopes, this comes to the same end state as without the surrounding box.

Appendix 3: The $\Psi_{2}$ model

Depending on the particular morphology of the lichen species, specific thallus layers are either located at the thallus surface or inside the thallus matrix. In this respect, water located in 'surface' layers (pool 1) is directly exposed to exchange processes with the atmosphere, whereas water located inside the thallus (pool 2) is in contact with pool 1-by means of intra- and extracellular water diffusion-but not directly with air. Thus the proportional share of each of these pools strongly depends on the species-specific morphology of the lichen. The ratio of exposed thallus layers versus internally located structures (Table 1) was used to receive a rough weighting of the size of these two pools for each of the investigated species. The authors are entirely aware that this simplified scheme does by no means illustrate the actual complexity 
of water diffusion and evaporation processes taking place in dehydrating lichens. For example it can be expected that, with progressive desiccation, evaporation fronts will shift from thallus margins to centre regions and/or towards more internally located thallus areas as the remaining water content of the distinct regions starts to deviate. Nevertheless, the authors believe that at any point during dehydration the remaining bulk thallus water can be separated in such more or less exposed water pools. In this respect, it is assumed that water only evaporates from the exposed 'surface' water pool $1, V_{\mathrm{L} 1}$, but that both water pools get proportionally smaller with evaporation. Water from the 'inside' water pool 2, $V_{\mathrm{L} 2}$, must pass through the outer 'surface' pool in order to evaporate. With $V_{\mathrm{L}}=V_{\mathrm{L} 1}+V_{\mathrm{L} 2}$, this means

$$
\begin{aligned}
\frac{\mathrm{d} V_{\mathrm{L} 1}}{\mathrm{~d} t} & =-E-\frac{\mathrm{d} V_{\mathrm{L} 2}}{\mathrm{~d} t} \\
\frac{\mathrm{d} V_{\mathrm{L} 2}}{\mathrm{~d} t} & =-E \frac{V_{\mathrm{L} 2}}{V_{\mathrm{L}}},
\end{aligned}
$$

which leads to

$\frac{\mathrm{d} V_{\mathrm{L} 1}}{\mathrm{~d} t}=-E \frac{V_{\mathrm{L} 1}}{V_{\mathrm{L}}}$.

The same is true for isotopically labelled water, but the two pools can also exchange their isotopic composition while there is no evaporation. So there is an extra exchange term for the isotopic compositions with the exchange coefficient $k_{\mathrm{ex}}$ :

$$
\begin{aligned}
& \frac{\mathrm{d} R_{\mathrm{L} 1} V_{\mathrm{L} 1}}{\mathrm{~d} t}=-R_{\mathrm{E}} E-R_{\mathrm{L} 2} \frac{\mathrm{d} V_{\mathrm{L} 2}}{\mathrm{~d} t}+k_{\mathrm{ex}}\left(R_{\mathrm{L} 2}-R_{\mathrm{L} 1}\right) \\
& \frac{\mathrm{d} R_{\mathrm{L} 2} V_{\mathrm{L} 2}}{\mathrm{~d} t}=-E \frac{V_{\mathrm{L} 2}}{V_{\mathrm{L}}} R_{\mathrm{L} 2}-k_{\mathrm{ex}}\left(R_{\mathrm{L} 2}-R_{\mathrm{L} 1}\right)
\end{aligned}
$$

Equations 17-21 therefore write

$$
\begin{aligned}
& V_{\mathrm{L} 1} \frac{\mathrm{d} R_{\mathrm{L} 1}}{\mathrm{~d} t}=-R_{E} E-\frac{R_{\mathrm{L} 1} V_{\mathrm{L} 1}+R_{\mathrm{L} 2} V_{\mathrm{L} 2}}{V_{\mathrm{L}}} E+k_{\mathrm{ex}}\left(R_{\mathrm{L} 2}-R_{\mathrm{L} 1}\right) \\
& V_{\mathrm{L} 2} \frac{\mathrm{d} R_{\mathrm{L} 2}}{\mathrm{~d} t}=-k_{\mathrm{ex}}\left(R_{\mathrm{L} 2}-R_{\mathrm{L} 1}\right)
\end{aligned}
$$

The first term on the right-hand side of the first line represents a change in isotopic composition due to evaporation. The second term represents the change due to the mixing of water of pool 1 with water coming from pool 2 and the last term represents diffusional exchange. The isotopic composition of pool 2 (second line) is only changing due to diffusional exchange because any advective flux leaving the pool does not change its isotopic composition.

Together with Eq. 8, this finally leads to the following two coupled differential equations that can be solved numerically:

$$
\begin{aligned}
\frac{\mathrm{d} R_{\mathrm{L} 1}}{\mathrm{~d} t}= & \alpha_{\mathrm{k}} \frac{h_{\mathrm{L}}}{1-h_{\mathrm{L}}} \frac{E}{V_{\mathrm{L} 1}} R_{\mathrm{a}} \\
& +\frac{1}{V_{\mathrm{L} 1}}\left(\frac{V_{\mathrm{L} 1}}{V_{\mathrm{L} 1}+V_{\mathrm{L} 2}} E-\alpha_{\mathrm{k}} \alpha^{+} \frac{1}{1-h_{\mathrm{L}}} E-k_{\mathrm{ex}}\right) R_{\mathrm{L} 1} \\
& +\frac{1}{V_{\mathrm{L} 1}}\left(\frac{V_{\mathrm{L} 2}}{V_{\mathrm{L} 1}+V_{\mathrm{L} 2}} E+k_{\mathrm{ex}}\right) R_{\mathrm{L} 2} \\
\frac{\mathrm{d} R_{\mathrm{L} 2}}{\mathrm{~d} t}= & \frac{k_{\mathrm{ex}}}{V_{\mathrm{L} 2}} R_{\mathrm{L} 1}-\frac{k_{\mathrm{ex}}}{V_{\mathrm{L} 2}} R_{\mathrm{L} 2}
\end{aligned}
$$

$R_{\mathrm{a}}$ is replaced by $R_{\mathrm{b}}$ as before in the case of the surrounding box (cf. Appendix 2) leading to the same differential form with different coefficients, identical as in the single pool case.

\section{References}

Beckett RP (1995) Some aspects of the water relations of lichens from habitats of contrasting water status studied using thermocouple psychrometry. Ann Bot 76:211-217

Belnap J, Büdel B, Lange OL (2001) Biological soil crusts: characteristics and distribution. In: Belnap J, Lange OL (eds) Biological soil crusts: structure, function and management (ecological studies 150). Springer, Berlin, pp 3-30

Bewley JD (1979) Physiological aspects of desiccation tolerance. Ann Rev Plant Physiol 30:195-238

Blum OB (1973) Water relations. In: Ahmadjian V, Hale ME (eds) The lichens. Academic Press, New York, pp 381-400

Büdel B, Scheidegger C (1996) Thallus morphology and anatomy. In: Nash TH III (ed) Lichen biology. Cambridge University Press, Cambridge, pp 37-64

Cappa CD, Hendricks MB, DePaolo DJ, Cohen RC (2003) Isotopic fractionation of water during evaporation. J Geophys Res 108:4525. doi:10.1029/2003JD003597

Cernusak LA, Wong SC, Farquhar GD (2003) Oxygen isotope composition of phloem sap in relation to leaf water in Ricinus communis. Funct Plant Biol 30:1059-1070

Cousins AB, Badger MR, von Caemmerer S (2006) A transgenic approach to understanding the influence of carbonic anhydrase on $\mathrm{C}^{18} \mathrm{OO}$ discrimination during $\mathrm{C}_{4}$ photosynthesis. Plant Physiol 142:662-672

Craig H, Gordon LI (1965) Deuterium and oxygen 18 variations in the ocean and the marine atmosphere. In: Tongiorgi E (ed) Stable isotopes in oceanographic studies and paleotemperatures. Laboratorio di Geologia Nucleare, Pisa, pp 9-130

Cuntz M, Ogée J, Farquhar GD, Peylin P, Cernusak LA (2007) Modelling advection and diffusion of water isotopologues in leaves. Plant Cell Environ 30:92-99

Dawson TE (1998) Fog in the California Redwood. Forest: ecosystem Inputs and use by plants. Oecologia 117(4):476-485

Dirmeyer PA, Gao X, Zhao M, Guo Z, Oki T, Hanasaki N (2006) GSWP2 multimodel analysis and implications for our perception of the land surface. Bull Am Meteorol Soc 87(10):1381-1397

Dongmann G, Nürnberg HW, Förstel H, Wagener K (1974) On the enrichment of $\mathrm{H}_{2}{ }^{18} \mathrm{O}$ in the leaves of transpiring plants. Radiat Environ Biophys 11:41-52

Epstein S, Mayeda T (1953) Variation of $\mathrm{O}^{18}$ content of waters from natural sources. Geochim Cosmochim Acta 4:213-224

Farquhar GD, Cernusak LA (2005) On the isotopic composition of leaf water in the non-steady state. Funct Plant Biol 32:293-303 
Farquhar GD, Gan KS (2003) On the progressive enrichment of the oxygen isotopic composition of water along leaves. Plant Cell Environ 26:1579-1597

Fletcher BJ, Beerling DJ, Brentnall SJ, Royer DL (2005) Fossil bryophytes as recorders of ancient $\mathrm{CO}_{2}$ levels: experimental evidence and a Cretaceous case study. Glob Biogeochem Cycles 19:GB3012

Gat J (2000) Atmospheric water balance-the isotopic perspective. Hydrol Proc 14:1357-1369

Gat JR, Matsui E (1991) Atmospheric water balance in the Amazon Basin: an isotopic evapotranspiration model. J Geophys Res 96:13179-13188

Gibson JJ, Aggarwal P, Hogan J, Kendall C, Martinelli LA, Stichler W, Rank D, Goni I, Choudhry M, Gat J, Bhattacharya S, Sugimoto A, Fekete B, Pietroniro A, Maurer T, Panarello H, Stone D, Seyler P, Maurice-Bourgoin L, Herczeg A (2002) Isotope studies in large river basins: a new global research focus. Eos Trans AGU 83(52):613-617

Gillon JS, Yakir D (2000) Internal conductance to $\mathrm{CO}_{2}$ diffusion and $\mathrm{C}^{18} \mathrm{OO}$ discrimination in C3 leaves. Plant Physiol 123:201-213

Goebel K (1926) Ein Beitrag zur Biologie der Flechten. Ann Jard Bot Buitenz 36:1-83

Hartard B, Máguas C, Lakatos M (2008) $\delta^{18} \mathrm{O}$ characteristics of lichens and their effects on evaporative processes of the subjacent soil. Isotopes Environ Health Stud 44:111-128

Helliker BR, Griffiths H (2007) Towards a plant-based proxy for the isotope ratio of atmospheric water vapor. Glob Change Biol 13:723-733

Helliker BR, Roden JS, Cook C, Ehleringer JR (2002) A rapid and precise method for sampling and determining the oxygen isotope ratio of atmospheric water vapor. Rapid Commun Mass Spectrom 16:929-932

Honegger R (1993) Developmental biology of lichens. New Phytol 125:659-677

Honegger R (1995) Experimental studies with foliose macrolichens: fungal responses to spatial disturbance at the organismic level and to spatial problems at the cellular level during drought stress events. Can J Bot 73:569-587

Honegger R (1996) Morphogenesis In: Nash TH III (ed) Lichen biology. Cambridge University Press, Cambridge, pp 65-87

Honegger R (1997) Metabolic interaction at the mycobiont-photobiont interface in lichens. In: Carroll GC, Tudzynski P (eds) Plant relationships. The Mycota V part A. Springer, Berlin, pp 209-221

Honegger R (2006) Water relations in lichens. In: Gadd GM, Watkinson SC, Dyer P (eds) Fungi and the environment Lichen Biology. Cambridge University Press, Cambridge, pp 185-200

Jahns HM (1984) Morphology, reproduction and water relations-a system of morphogenetic interactions in Paremlia saxatilis. In: Hertel $\mathrm{H}$, Oberwinkler $\mathrm{F}$ (eds) Beiträge zur Lichenologie. Festschrift J. Poelt. Beiheft zur Nova Hedwigia 79. J. Cramer, Vaduz, pp 715-737

Fontes JCh, Gonfiantini R (1967) Comportement isotopique au cours de l'evaporation de deux bassins Sahariens. Earth Planet Sci Lett 3:258-266

Jonsson AV, Moen J, Palmqvist K (2008) Predicting lichen hydration using biophysical models. Oecologia 156:259-273

Kappen L (1988) Ecophysiological relationships in different climatic regions. In: Galun M (ed) Handbook of lichenology, vol 2. CRC Press, Boca Raton, pp 37-100

Kendall C, McDonnell JJ (eds) (1998) Isotope tracers in catchment hydrology. Elsevier, Amsterdam

Lai C-T, Riley W, Owensby C, Ham J, Schauer A, Ehleringer J (2006) Seasonal and interannual variations of carbon and oxygen isotopes of respired $\mathrm{CO}_{2}$ in a tallgrass prairie: measurements and modeling results from three years with contrasting water availability. J Geophys Res 111:D08S06
Lai C-T, Ometto JP, Berry JA, Martinelli LA, Domingues TF, Ehleringer JR (2008) Life form-specific variations in leaf water oxygen-18 enrichment in Amazonian vegetation. Oecologia 157(2):197-210

Lakatos M, Hartard B, Máguas C (2007) The stable isotopes $\delta^{13} \mathrm{C}$ and $\delta^{18} \mathrm{O}$ of lichens can be used as tracers of microenvironmental carbon and water sources. In: Dawson TE, Siegwolf RTW (eds) Stable isotopes as indicators of ecological change. Terrestrial Ecology Series, Elsevier, Oxford, pp 73-88

Lange OL (1969) $\mathrm{CO}_{2}$-Gaswechsel von Moosen nach Wasserdampfaufnahme aus dem Luftraum. Planta 89:90-94

Lange OL, Kidron GJ, Buedel B, Mayer A, Killian E, Abeliovich A (1992) Taxonomic composition and photosynthetic characteristics of the biological soil crusts covering sand dunes in the western Negev Desert. Funct Ecol 6:519-527

Lange OL, Green TGA, Heber U (2001) Hydration-dependent photosynthetic production of lichens: what do laboratory studies tell us about field performance? J Exp Bot 52:2033-2042

Langendörfer U, Cuntz M, Ciais P, Peylin P, Bariac T, Milyukova I, Kolle O, Naegler T, Levin I (2002) Modelling of biospheric $\mathrm{CO}_{2}$ gross fluxes via oxygen isotopes in a spruce forest canopy: a ${ }^{222} \mathrm{Rn}$ calibrated box model approach. Tellus 54B:476-496

Larson DW, Kershaw KA (1976) Studies on lichen dominated systems XVIII. Morphological control of evaporation in lichens. Can J Bot 54:2061-2073

Lee X, Smith R, Williams J (2006) Water vapour ${ }^{18} \mathrm{O} /{ }^{16} \mathrm{O}$ isotope ratio in surface air in New England USA. Tellus 58B:293-304

Máguas C, Brugnoli E (1996) Spatial variation in carbon isotope discrimination across the thalli of several lichen species. Plant Cell Environ 19:437-446

Majoube M (1971) Fractionnement en oxygène 18 et en deutérium entre l'eau et sa vapeur. J Chim Phys 68:1423-1436

Nash TH III (1996) Photosynthesis, respiration, productivity and growth. In: Nash TH III (ed) Lichen biology. Cambridge University Press, Cambridge, pp 88-120

Palmqvist K, Badger MR (1996) Carbonic anhydrase(s) associated with lichens: In vivo activities, possible locations and putative roles. New Phytol 132:627-639

Proctor MCF, Nagy Z, Zs Csintalan, Takács Z (1998) Water-content components in bryophytes: analysis of pressure-volume relationships. J Exp Bot 49:1845-1854

Rawlins SL (1972) Theory of thermocouple psychrometers for measuring plant and soilwater potential. In: Brown RW, van Haveren BP (eds) Psychrometry in water relations research. University Logan Utah Agricultural Experiment Station, Utah State, USA, pp 43-50

Reyes-García C, Mejia-Changi M, Jones GD, Griffiths H (2008) Water vapour isotopic exchange by epiphytic bromeliads in tropical dry forests reflects niche differentiation and climatic signals. Plant Cell Environ 31:828-841

Rundel PW (1988) Water relations. In: Galun M (ed) Handbook of lichenology, vol 2. CRC Press, Boca Raton, pp 17-36

Silverman DN (1982) Carbonic anhydrase: oxygen-18 exchange catalyzed by an enzyme with rate-contributing proton-transfer steps. Meth Enzym 87:732-752

Tyree MT, Jarvis PG (1981) Water in tissue and cells. In: Lange OL, Nobel PS, Osmond CB, Ziegler H (eds) Encyclopedia of plantphysiology. New series. Physiological plant ecology, vol 12B. Springer, Berlin, pp 35-77

Yakir D, Wang X-F (1996) Fluxes of $\mathrm{CO}_{2}$ and water between terrestrial vegetation and the atmosphere estimated from isotope measurements. Nature 380:515-517

Yakir D, DeNiro MJ, Rundel PW (1989) Isotopic inhomogeneity of leaf water: evidence and implications for the use of isotopic signals transduced by plants. Geochim Cosmochim Acta 53:2769-2773 